\title{
Sustainability Analysis for Irrigation Water Management in the Aral Sea Region
}

\author{
Ximing Cai ${ }^{1}$, Daene C. McKinney ${ }^{2}$, Mark W. Rosegrant ${ }^{1}$ \\ ${ }^{1}$ International Food Policy Research Institute, Washington DC, 20006. \\ ${ }^{2}$ Department of Civil Engineering, University of Texas, Austin, TX 78712 \\ x.cai@cgiar.org daene@aol.com m.rosegrant@cgiar.org
}

\begin{abstract}
Sustainable irrigation water management should simultaneously achieve two objectives: sustaining irrigated agriculture for food security and preserving the associated natural environment. A stable relationship should be maintained between these two objectives now and in the future, while potential conflicts between these objectives should be mitigated through appropriate irrigation practices. The Aral Sea region in Central Asia is a region that is known for the conflict between sustaining irrigated agriculture and rehabilitating the environment. The current status of irrigation water management in the region demonstrates that the Aral Sea disaster is a prime example of unsustainable irrigation development. This paper presents an integrated modeling framework for sustainable irrigation management analysis and applies it to analyze irrigation water management in the Aral Sea region. Based on the modeling results, alternative futures of the irrigation practice in the region are explored and it is found that maintaining current irrigation practices will lead to worse environmental and economic consequences. Investments in infrastructure improvements (an annualized amount of about US\$299 million) and crop pattern changes are necessary to sustain the irrigated agriculture and the associated environment in the region. Moreover, a penalty tax on salt discharge less than US\$50 per ton as an economic incentive may help address environmental problems, while having only a small effect on irrigation profit.
\end{abstract}

Keywords: Irrigation Water Management, Sustainability; System Analysis; Aral Sea, Syr Darya basin 


\section{INTRODUCTION}

Over the last 30 years irrigated areas have increased rapidly, helping to boost agricultural output and feed a growing population. Irrigation uses the largest fraction of water in almost all countries. Globally, 70 percent of freshwater diverted for human purposes goes to agriculture, and irrigation water demand is still increasing because the area being irrigated continues to expand. In some countries, the expansion of surface water use appears to be approaching the physical limit, and groundwater abstractions are increasingly exceeding rates of replenishment. Meanwhile, industrial and domestic water demand has been increasing rapidly as a result of increasing economic development and urbanization. In some countries and regions, water is already being transferred out of irrigation and into urban-industrial uses, putting additional stress on the performance of the irrigation sector (Rosegrant and Ringler 2000).

Although the achievements of irrigation in ensuring food security and improving rural welfare have been impressive, past experience also indicates problems and failures of irrigated agriculture. In addition to large water use and low efficiency, environmental concerns are usually considered the most significant problem of the irrigation sector. Environmental problems include excessive water depletion, water quality reduction, waterlogging, and salinization. The marked reduction in annual discharge of some of the world's major riversevident in long-term hydrological records (OECD 1998) - has been attributed, in part, to the large water depletion caused by irrigated agriculture. In some basins, excessive diversion of river water for irrigation (and other uses) has brought environmental and ecological disasters to downstream areas, and groundwater pumping at unsustainable rates has contributed to the lowering of groundwater tables and to saltwater intrusion in some coastal areas. Many water 
quality problems have also been created or aggravated by changes in streamflows associated with agriculture's consumptive uses. Moreover, inappropriate irrigation practices, accompanied by inadequate drainage, have often damaged soils through over-saturation and salt build-up. The United Nations Food and Agriculture Organization (FAO) estimates that 60 to 80 million hectares are affected to varying degrees by waterlogging and salinity (FAO 1996). Finally, these irrigation-induced environmental problems threaten not only agricultural production systems but also human health and the environment.

"Can the irrigation miracle last"? The role of irrigation water management in food security has been receiving substantial attention in recent years (e.g., Postel, 1999). Increasingly, researchers and policymakers are advocating sustainable development as the best approach to today's and future water problems (Loucks 2000). Sustainable development-that is, development that meets the needs of the present without compromising the ability of future generations to meet their own needs - is a concept that has gained popularity since publication of the 1987 Brundtland Commission Report (WCED 1987). In light of sustainability, irrigation water management should simultaneously achieve two objectives: sustaining irrigated agriculture for food security and preserving the associated natural environment. A stable relationship should be maintained between these two objectives now and in the future, while potential conflicts between these objectives should be mitigated through appropriate irrigation practices. This paper focuses on achieving a sustainable balance between irrigation management - the largest water use worldwide - and environmental preservation, through a case study of the irrigation management in the Aral Sea region in Central Asia, which may have experienced the most serious environmental disaster caused by excessive irrigation (Micklin 1993). 
This paper will first examine irrigation water management in the Aral Sea region against sustainability principles, taking account of risk minimization in water supply, environmental conservation, equity in water allocation, and economic efficiency in water infrastructure development. Following that we describe an integrated modeling framework for sustainability analysis in irrigation water management, and then apply the modeling framework to the Aral Sea region. Alternative futures of the irrigation practice in the region are explored through the systems modeling analysis, with regard to irrigated area change, infrastructure investment, irrigation versus hydropower development, and application of economic incentives.

\section{EXAMINATION OF IRRIGATION MANAGEMENT IN THE ARAL SEA REgion AgAinT SUSTAINABILITY CRITERIA}

\section{1. "Creeping" Environment Changes in the Aral Sea Region}

The Aral Sea, a land-locked lake, is located in the semi-arid and desert areas of Central Asia (Figure 1). Its level is determined by the inflow of two feeding rivers, the Amu Darya River and the Syr Darya River. The average inflows from the Amu Darya and the Syr Darya rivers once were 72 cubic kilometers $\left(\mathrm{km}^{3}\right)$ and $37 \mathrm{~km}^{3}$ per year, respectively, but have now decreased to a mere trickle because of large-scale irrigation water withdrawals and high water consumption during water distribution, conveyance, and field application. Compared with the status in 1960 when the Aral Sea was the world's fourth largest inland lake, by the early 1990s the lake had shrunk to about half its size, was 16 meters below its former level, and three times as salty (Micklin 1993). Figure 2 shows the evolution of the surface area of the Aral Sea and of the irrigated areas in the basin over the last 80 years. In fact, the effects of extensive irrigation in the Aral Sea basin extend far beyond the fate of the sea itself. Thirty-five million people have lost access to the lake's water, fish, reed beds, and transport functions. Moreover, far-reaching 
environmental and ecological problems, such as dust storms, erosion, and poor water quality for drinking and other purposes, have negatively affected human health and economic development in the region. Thus, the Aral Sea disaster is the prime example for unsustainable irrigation development: rapid, large-scale expansion; sole reliance on high-water-use production systems for cotton and rice; poor water distribution and drainage; inefficient irrigation techniques resulting in enormous losses of irrigation water; and large-scale, non-dose-related uses of fertilizers and pesticides.

Glantz (1999) argues that the Aral Sea region has experienced "creeping" environmental changes, that is, slow-onset, low-grade, and cumulative. These creeping changes can be seen in Figure 3, which shows the upstream and downstream runoff during 1959-98. The year 1960 is typically considered the beginning of the deterioration. A so-called "pre-problem" stage started in the mid-1960s, when the first signs of adverse environmental effects began to appear. The downstream flow depletion became more apparent during 1976-81 and full-fledged during 1981-85. The final widespread recognition of the Aral Sea crisis dates to 1986-87, when several threshold levels had been surpassed. Actions to solve the problem began only in 1990 . Unfortunately, by that time, the environmental costs resulting from excessive irrigation surpassed the economic capacity of the newly independent republics in Central Asia (World Bank 1992).

One indicator of the increasing environmental deterioration in the basin was the change in crop yields, as irrigation-induced water quality and soil quality problems led to a reduction in yields. Figure 4 shows the average annual growth rates of seed cotton yield in three Central Asian countries during different periods. All three countries achieved positive growth during 1960-80, but growth turned negative in the 1980s. Moreover, the downstream country of 
Kazakhstan experienced a larger cotton yield reduction, likely because of more serious water and soil quality degradation. Although the changes in the political and economic situation in the region also likely contributed to the decline in agricultural production in the basin, a significant share was probably caused by growing water and soil quality problems.

For a closer look at sustainability issues in irrigation management, we examine these issues in greater detail in one of the two major basins in the Aral Sea region, the Syr Darya River basin. The river begins at the Pamir and Tien Shan plateaus, crosses the territories of four Central Asia republics (Kyrgyzstan, Tajikistan, Uzbekistan, and Kazakhstan), and terminates in the Aral Sea. The basin's water supply system comprises 9 major tributaries, 11 reservoirs, 23 irrigation distribution systems, and numerous distribution canals.

\subsection{Irrigation Management in the Syr Darya River Basin}

\subsubsection{Risk and Vulnerability of the Water Supply System}

Table 1 shows total renewable water resources, total water withdrawals, and the ratio of withdrawals to water availability in the Syr Darya River basin for selected years from 1961 to 1990 (Glantz 1999). Even in the early 1960s, the basin system was vulnerable in dry years (1961 was a dry year). The high ratios of water withdrawals to renewable water in 1980 and 1990 show that a considerable amount of water in the basin might be reused even in average years.

Raskin et al. (1992) categorized five hydrologic patterns in the basin, with probabilities of occurrence of 3.3 percent (very wet), 16.7 percent (wet), 52.0 percent (normal), 21.3 percent (dry), and 6.7 percent (very dry). The ratio of annual inflow under various hydrologic levels to the normal level is 1.27 (very wet), 1.12 (wet), 1.00 (normal), 0.76 (dry), and 0.59 (very dry). Dry and very dry years occur with a probability of 28 percent. If water withdrawals are at 1990

levels $\left(53.0 \mathrm{~km}^{3}\right)$, then the ratio of withdrawal to runoff needs to be as high as 1.9 in dry years, 
and 2.4 in very dry years to meet demands. This can only be achieved at high return flow reuse levels. However, because of the high evaporation loss in the region, 70 to 80 percent of water withdrawals are consumed in the basin. Therefore, water withdrawals in dry and very dry years cannot meet the demand at the 1990 level.

Another indicator of water shortage in the basin is per capita water availability, which was estimated at 7,500 cubic meters $\left(\mathrm{m}^{3}\right)$ in $1950,2,000 \mathrm{~m}^{3}$ in 1980, and $700 \mathrm{~m}^{3}$ in 2000 (Klotzli 1994). When the per capita water availability is $1,000 \mathrm{~m}^{3}$, the system can suffer high vulnerability (Gleick 2000). This indicator shows that the water supply system in the Syr Darya could be very vulnerable.

\subsubsection{Environmental and Ecological System Degradation}

Decline of flow to the Aral Sea

Climate changes including changes of air temperature and precipitation exists (temperature increased by less than $1{ }^{\circ} \mathrm{C}$ over both mountains and plains; annual total precipitation reduced by $16 \mathrm{~mm}$ within 10 years over mountains during 1960-1985, and no systematic observation in precipitation change over plains. Zolotokrylin, (1999)), but high irrigation water withdrawals and the large evaporation losses in the basin are widely recognized as the major cause for the tremendous decline in flow into the Aral Sea. As shown in Figure 3, the decline of downstream flows started in the mid-1960s. Outflows to the lake dropped to a mere trickle in the mid-1970s, with increases only achieved in the 1990s when the Aral Sea problem was first addressed. However, recent inflows to the lake are not sufficient to reverse the disaster situation. The level, area, and volume of the sea during 1989-98 are shown in Figure 5. Thus, even in the last decade, the drying up of the sea has not slowed and, in fact, the problem has worsened. 


\section{Degradation of soils}

Previously fertile, humus-rich, meadow-swamp soils in delta areas in the zone of influence of irrigation have been transformed into low-productivity, sandy-desert soils with much lower fertility. In the early 1990 s, 50 percent of the land in the basin was classified as saline. The soil salinity problem varies along the river. In the upper reaches, less than 10 percent of the land has moderate to strong salinity, while in downstream areas more than 50 percent of the irrigated lands are classified as moderately to strongly saline. Salinization is rapidly increasing in the midstream areas that are irrigated with water from the Syr Darya River. For example, the percentage of moderately to strongly saline lands in the midstream area increased from approximately 26 percent in 1970 to 54 percent in 1995 (EC 1995). Salinization is contributing to the diminishing crop yields and is also creating a health problem because of its effect on potable water supplies. Other irrigation-related soil problems include waterlogging, erosion, and compaction (Klotzli 1994).

\section{Water quality reduction}

Although the quality of the natural flows in the Syr Darya meets international water quality standards, it has been adversely affected by anthropogenic activities. Agricultural drainage is the major factor affecting water quality in the middle and lower sections of the basin. Records show that just downstream of the Fergana Valley, a major irrigation district in the upper basin, the average salinity of the river water increases to 1.2 grams per liter (g/l) from a concentration of less than $0.5 \mathrm{~g} / 1$ entering the valley (Raskin et al. 1992). Salinity conditions vary significantly along the river from upstream to downstream. The mineralization is $0.2-0.7$ $\mathrm{g} / 1$ in the upstream area, $0.7-2.3 \mathrm{~g} / 1$ in the midstream area, and $9.0-10.0 \mathrm{~g} / 1$ in the downstream area (EC 1995, Vol. II). Figure 6 plots salinity at selected points in the Syr Darya River from 1950 to 1990 . Some stability and even improvement in the water quality has been achieved over 
the last 10 years from improved water distribution and irrigation and drainage facilities. Whereas downstream areas suffer most from water and soil salinity problems, some upstream areas, such as the Fergana Valley, also suffer substantial groundwater salinization. The highest surface water salinity usually occurs at the midstream reach (inflow to the Kayrakum Reservoir), because of the large drainage load from the Fergana Valley and other upstream and midstream demand sites.

\subsubsection{Conflicts in Water Sharing}

The Syr Darya River basin is a vital resource for its four Central Asian riparian countries. The transboundary character of the river is a source of tension and conflict among the countries as water allocation directly affects agricultural production and hydroelectric generation. An inequitable allocation of water among the four nations could significantly hurt the economic position of one or more of the republics. Before 1990, unified water management in the Aral Sea region was carried out under the Soviet law system. Since 1990, the new border situation in Central Asia has created clear-cut upstream-downstream conflicts between the independent countries. All the republics asserted their right to control land, water, and other natural resources within their territories, increasing the complexity of the Aral Sea disaster. Although centralized water management authorities (basin water management agencies) were established for the river basins of the Amu Darya and Syr Darya, for the time being, intergovernment agreements remain the major institution for regulating water allocation among the Central Asian republics.

Typical upstream-downstream water conflicts in the Syr Darya River basin include water depletion, timing problems created by water storage for hydropower production, and water quality deterioration in the lower reaches. Kyrgyzstan controls most of the source flow (70

percent of the runoff) as well as most of the reservoirs regulating the river flow. Uzbekistan, the 
most populous republic in the region, has only minimal hydraulic control along the course of the river. Kyrgyzstan, which depends on hydropower for most of its energy supply, especially in the winter, wants to save summertime runoff in its reservoirs (Toktogul, the largest in the basin with

an active capacity of $14 \mathrm{~km}^{3}$ ) for hydropower generation in the winter. This causes a major conflict with the downstream republics, which depend on irrigation in the summer growing season. Moreover, Kazakhstan, located downstream of Uzbekistan water uses, complains about low levels of both water quantity and quality, including high concentrations of salt and industrial toxic wastes.

\subsubsection{Infrastructure Deterioration}

Since independence, the Central Asian republics have lost significant management capacity which has yet to be replaced. Much of the capital that had been accumulated by the former Soviet system has been either consumed or dissipated. As a result, maintenance of important infrastructure such as irrigation and drainage systems and roadways has been deferred; and farm equipment and irrigation machinery are not being adequately serviced and replaced in a timely manner. In all five countries of Central Asia, most irrigation systems are in a state of disrepair. The water control and distribution system is deteriorating, and the aging water supply systems are at risk. Mining and industrial wastes are not monitored, and treatment facilities are not designed to remove industrial toxic wastes. Pollution from industrial mines and uranium enrichment facilities are a major concern. As pollution and water quality problems move downstream to the neighboring republics, they have the potential to cause interstate conflict. Furthermore, the five Central Asian governments, each advancing its own national interest within a regional context, have had to assume operations of systems within their own borders; 
and large areas of formerly irrigated land have been lost because of the breakdown of the water system.

The water supply and utilization infrastructure in the Aral Sea region requires extensive maintenance and new capital investment. Yet the governments have inadequate financial resources to devote to the energy system; and without major reform, they have little ability to recoup the costs of any expenditure they could make (World Bank 1992).

\subsubsection{Potential Approaches to the Aral Sea Problem}

The economic and environmental problems in the Aral Sea region will likely worsen. The population could increase by as much as 35 percent over the next 30 years according to the United Nations (UNESCO 1998). That population growth will increase demands on irrigated agriculture and water resources as the republics promote food self-sufficiency. Additional urban development will further challenge the water supply situation. These problems raise the question of whether such a high level of irrigated agriculture can be sustained while preventing or minimizing adverse environmental and ecological impacts. The answer is at the heart of sustainable water resources management for the basin. Glantz (1999) argues, "It is important that the Aral Sea basin be viewed historically as a 'meta-ecosystem:' a system that cannot be separated into its many linked parts. Collective problems must be met with collective solutions." According to Micklin (1993), the huge hydrogeological changes will take decades to reverse. Reducing the amount of water used for irrigation will have to be part of the solution. However, the economic reliance on a few monoculture crops leaves little room for change (World Bank 1992).

The approaches being suggested to solve the Aral Sea problem include both structural and managerial improvements. Considerable space exists to reduce irrigation withdrawals 
through improvements in the water distribution and conveyance systems and in the irrigation and drainage systems (Cai 1999). Managerial improvements include structural reforms in agriculture, for example, replacing water-consuming crops, such as cotton and rice, with relatively water-saving crops such as wheat and maize (Micklin 1993), and implementing water prices (as is being done in some form in each republic) (Hutchens and Mann 1998).

Within the region, there are currently very few practical applications of an integrated approach to managing natural resources. Demonstrations of actual applications of environmental management policies are needed to test the effectiveness of the policies and to introduce new technology. An analytical framework that includes the costs and benefits of these approaches is needed to see the effects of these approaches today and in the future, and to look at the likelihood these approaches can make the region's unsustainable water management sustainable.

\section{MOdeling FramewOrk FOR SUSTAINABILITY ANALYSIS}

Previous studies have set out many guidelines for sustainable water resources management (UNCED 1992; Serageldin 1995; and ASCE and UN/IHP 1998; Loucks 2000). No doubt these guidelines could provide some assistance and guidance to those who are actually involved in planning and decisionmaking in specific regions. However, these broad guidelines still need to be translated into operational concepts that can be applied to the planning and management of water resources systems in specific basins. In this paper we discuss an analytical framework for sustainability analysis in irrigation. This framework is then applied to the Aral Sea region.

\subsection{Decision- Making Analysis in Irrigation Water Management in a River Basin Scope}


In this section, we discuss a modeling framework for sustainability analysis of irrigation water management in a river basin scope. A river basin forms a natural boundary for water resources planning and management, in which water interacts with and to a large degree controls the extent of other natural components in the landscape such as soils, vegetation and wildlife. Human activities may also be organized and coordinated within the river basin unit. Physical processes, such as flow and constituent balances, are governed by natural laws, and are also affected by human actions, including impoundment, diversion, irrigation, drainage, and discharges from urban areas. Therefore, decision-making in water resources management should be based on physical processes, and should also take account of artificial "hardware" (infrastructure) and "software"(management policies). A modeling framework can help to identify and analyze the decision issues at in the context of the river basin.

Figure 7 presents a diagram of a modeling framework for decisionmaking, showing decision options at the river basin and farm (demand sites) levels. Water can be used for instream purposes, including hydropower generation, recreation, and waste dilution, and for offstream purposes that are differentiated into agricultural, municipal, and industrial water uses. The rapid increase in municipal and industrial water demand in many regions of the world will likely not only require increasing transfers of water out of agriculture but also lower the quality of downstream irrigation water if municipal and industrial wastewater discharge is not appropriately controlled. Taking into account instream water requirements for hydropower generation, recreation, and ecological uses involves setting aside sufficient water over space, time, and distribution between instream and offstream water uses.

The social benefit of water uses should be an important component of a basin water management strategy. That means both the positive contribution from the economic value of 
irrigated agriculture and the environmental damage from salinity and waterlogging, soil erosion, and water quality degradation resulting from irrigation. The social benefit also relates to the benefits and costs of municipal and industrial (M\&I) water uses.

The basin water management system should be governed by national or regional agricultural policies, including trade and macroeconomic policies, agricultural input and output prices, government investments in technology and infrastructure, and institutional resource management policies, such as market quotas, water allocation policies, and soil conservation programs. Policy instruments applied directly to water management could include a mix of water prices, penalty taxes on waste discharge and irrigation drainage, and water rights. The impact of these policies on agricultural sector growth and on environmental sustainability in the region should be analyzed along with decisions on water management at the basin/sub-basin and farm levels.

Decisions at the basin/sub-basin and farm levels may be considered separately. Decisions at the basin/sub-basin level should promote an appropriate expansion of infrastructure capacity and optimal operation of existing reservoir, aquifer, and stream systems. They should also take into account water allocation among different sectors and users, especially in transboundary situations, as well as the interaction between those sectors and users. While keeping in mind water rights within a basin, decision makers should consider the efficiency with which water is used at different places in the basin by different users and the degree to which different uses degrade the water quality (Batchelor 1999). Efficiency at the river basin level can be improved by (1) increasing output per unit of evaporated water, (2) reducing losses of usable water to sinks, (3) reducing water pollution, and (4) reallocating water from lower valued to higher valued uses (Seckler 1996). 
Batchelor (1999) suggest several ways to improve physical and economic efficiency at the farm level:

- agronomic (for example, improving crop husbandry and cropping strategies);

- technical (for example, installing an advanced irrigation system);

- managerial (for example, adopting demand-based irrigation scheduling systems and better maintaining equipment); and

- institutional (for example, introducing water pricing and improving the legal environment).

Supply and demand management policies may also affect decisionmaking. A portion of the growing demand for water can be met by investing in water supply and utilization systems, and some potential exists for expanding nontraditional sources of water supply (for example, desalinization). However, in many arid or semi-arid areas, water is no longer abundant, and the high economic and environmental costs of developing new water resources limit how much supply can expand. Demand management aims to better utilize existing water resources by curbing inessential or low-value uses through price or nonprice measures. The modeling framework should provide information to analyze trade-offs between the decisions for the two categories. In most cases, new sources and improved demand management are both necessary, and joint decisions for supply and demand should be made for sustainable water resources management.

These water management issues, policies, and decisions are complex and integrated with the social, economic, and environmental development and sustainability of the basin. In order to guide the process of achieving sustainable water management, a framework for decision support is needed. This framework should be a dynamic system that includes modeling components 
capable of analyzing the effects of the proposed policies and strategies over periods of time long enough to see the cumulative, long-term effects on the system. The components shown in Figure 7 are interrelated, and the interrelationships vary as external inputs (for example, climate variation, population increase, investment in infrastructure) change over time. Some key components in the modeling framework as described as bellows:

\section{Integrated Hydrologic-Agronomic-Economic Modeling Components}

The interdisciplinary nature of water resources problems requires the integration of technical, economic, environmental, social, and legal aspects into a coherent analytical framework, so that both economic and environmental consequences of policy choices can be examined. Hydrologic relationships provide a physical basis to evaluate water availability and water quality conditions. Accurate estimates of deep percolation, return flows, and their contaminant concentrations, as well as groundwater levels, are essential to evaluate the environmental effects of irrigation. Assessing the damage resulting from the depletion of water over time is also critical to evaluating the environmental effects of irrigation. Long-term simulations of these processes are necessary to trace the cumulative consequences such as waterlogging, soil salinization, and groundwater quality reduction.

Crop production functions connect water, soil, and other inputs with crop production, which is the fundamental building block for estimating the demand for and value of water in irrigation. An ideal crop-water production model should be flexible enough to address issues at the crop, farm, and basin levels. The production function should allow the assessment of policyrelated problems and, in particular, be sufficiently comprehensive to allow the estimation of externality effects. Moreover, the modeling framework should generally include the valuation of nonagricultural uses of water, such as values for domestic demand; commercial, industrial, and 
mining demand; recreational demand; and environmental demands such as maintenance of instream river flows and flushing of pollutants. (See McKinney et al. (1999) for a comprehensive review of agricultural and nonagricultural water valuation.)

Only by considering all interactive components that benefit from or damage the resource can the optimal use be established from a social standpoint. Thus, with the growing scarcity of water and increasing competition for water across sectors, the economic aspects of water allocation are increasingly important in river basin management. Important economic issues that need to be examined through integrated economic-hydrologic river basin modeling include transaction costs, the effects of allocation mechanisms on agricultural productivity, intersectoral water allocation, the environmental effects of allocations, and property rights for different allocation mechanisms (Rosegrant and Meinzen-Dick 1996). Moreover, institutional relationships present directives aimed at achieving equity in water resources management.

An integrated system should be able to explore the interdependence between economic development and environmental consequences, and between short-term decisions and potential long-term problems. The outcomes of water use can then be examined in terms of efficiency, equity, and environmental impact. Over time, these outcomes change the environment through processes such as salinization and waterlogging, siltation, industrial water pollution, technological change, crop diversification, and legislative and institutional change. These processes are critical for understanding the dynamic changes occurring in the environment associated with water use systems, and for implementing appropriate controls on the actions that drive the system to sustainability thresholds.

\section{Integrated Short-Term and Long-Term Objectives}


Irrigation water planning and management should balance short-term and long-term objectives. They are neither totally consistent nor totally in conflict with each other. Short-term objectives focus on current benefits, while long-term objectives aim to sustain current and expected benefits into the future. Long-term decisions must account for the long-term consequences of short-term decisions in a way that avoids possible negative future effects of current decisions. Put another way, the long-term situation improves when short-term decisions balance current and future benefits.

\section{System Performance Control Based on Sustainability Criteria}

Criteria based on sustainability principles in water resources management can be quantified in terms of risk minimization in water supply, environmental conservation, equity in water allocation, and economic efficiency in water infrastructure development (Cai, 1999). These criteria will be incorporated into the modeling framework so that system performance can be evaluated and controlled in light of system sustainability. This approach will then translate broad guidelines for sustainable water resources management into operational concepts that can be applied to water management in irrigation-dominated river basins.

\subsection{A Prototype Modeling Framework for Sustainability Analysis}

A long-term dynamic modeling framework following the concepts and methodology discussed above was developed and reported in the dissertation of Cai (1999). Figure 8 shows a diagram of the modeling framework. The core of the modeling framework is an Inter-Year Control Program $(I Y C P)$ and a sequence of Yearly Models (YMs). The yearly model for year $y$, $Y M^{y}$, is a short-term (annual) optimization model developed at the river basin scale. The objective function of the model is to maximize total water use net benefit in a river basin for that year. The model includes essential integrated hydrologic, agronomic, and economic components 
such as (1) flow and pollutant (salt) transport and balance in the river basin network, including the crop root zone; (2) irrigation and drainage processes; (3) crop production functions, including the effects of both water stress and soil salinity; (4) benefit functions for both instream and offstream uses, accounting for economic incentives for salinity control and water conservation; (5) tax and subsidy systems to induce efficient water allocation, improve irrigation-related capacities, and protect the environment; and (6) institutional rules and policies that govern water allocation.

The model is based on a node-link network with source nodes-such as rivers, reservoirs, and groundwater aquifers - and demand site nodes — such as agricultural, municipal and industrial (M\&I), and ecological demand sites, and hydropower stations. Detailed agricultural water demand, instream water uses (including flow release for environmental and ecological use), and hydropower generation are modeled. Details of the yearly model can be found in Cai (1999). In addition, McKinney et al. (1999) provides a comprehensive review of integrated, hydrologic-agronomic-economic models at the basin scale; and Rosegrant et al. (2000) illustrates the application of such a model to the Maipo basin in Chile.

The IYCP is a long-term model which uses some prescribed indicators based on sustainability criteria to control relations between short-term irrigation practices and their longterm socioeconomic and environmental consequences (see Figure 7). The long-term decisions include the regulation of inter-year reservoir storage, irrigation and drainage infrastructure improvements, changes in irrigated area and crop patterns, and economic incentives (for example, salt penalty taxes.) The thesis of this framework is that short-term (intra-year) decisions should be controlled by long-term (multi-year) sustainability criteria to reach sustainable planning and management decisions. 
The long-term optimization/simulation model of the basin incorporates specific indicators of sustainability, taking into account risk minimization in water supply, environmental conservation, equity in water allocation, and economic efficiency in water infrastructure development. These indicators are measured by some approximate methods. Risk is represented by reliability, reversibility, and vulnerability in terms of sustained irrigated area and flow for ecological use, reflecting how much irrigated area/ecological flow can be sustained, how often irrigated area/ecological flow drops below an assumed target, and how serious the deficits are in a long-term time horizon (30 years). Environmental indicators are identified as worst water and soil salinity conditions in the basin over the long run. Temporal equity ("now and then") is defined as the standard deviation of the rate of change of total water use benefit in the basin over all years; and spatial equity ("here and there") is defined as the standard deviation of the average rate of change of water use benefit over all demand sites. Economic indicators are represented by the ratio of the marginal benefits to the marginal costs of additional water infrastructure improvements. Mathematical representations of these indicators are given in Cai, et al. (2001).

The results of the sequence of yearly models $\left(Y M^{y}\right)$, over a long time horizon under a particular selection of the inter-year decision variables, are used to calculate the indicators, which are then used to evaluate the long-term performance of some policy options represented by the long-term decision variables. To find optimal long-term policies, these modeling processes are implemented in an iterative form as shown in Figure 8. The solution approach to the modeling framework is presented in Cai, et al. (2001).

\section{Policy Implications for IrRigation PlanNing AND MaNagement - Results From THE MOdeling Framework}


The modeling framework described in section 3 has been applied to the Syr Darya River basin in Central Asia over a 30-year period with various hydrologic levels such as very wet $(v w)$, wet $(w)$, normal $(n)$, dry $(d)$, and very dry $(v d)$. The hydrologic levels were projected by Raskin et al. (1992) and are shown in Figure 9 and other figures. Several policy scenarios have been studied using the model. On the basis of the modeling results, policy implications for planning and management of irrigation water in the basin are discussed in the following.

\subsection{Maintaining Current Irrigation Practices}

Maintaining current irrigation practices will put the flow to the Aral Sea at tremendous risk. Assuming the irrigated area will start to decline when crop yields drop below half their maximum value, the first scenario maintains the current irrigated area and crop patterns without improvements to the irrigation and drainage infrastructure. This is defined as the baseline scenario (BAS). This scenario shows that 97 percent of the currently irrigated area can be used during the 30-year study period; there are no years in which a cutback in planted area of more than 15 percent is required; and the largest annual cutback of irrigated area in the time horizon (30 years) is 11 percent.

Compared to the relatively low risk to irrigation under BAS, the risk to ecological water use is tremendous. Ecological water use is measured as the flow into the Northern Aral Sea from the Syr Darya River. To consider the risk indicators for ecological water use, we define the target flow as the average flow to the Northern Aral Sea from the river during 1965-75. That flow satisfies the inflow requirement to the Aral Sea from the Syr Darya River according to the five-country agreement on flow to the Aral Sea (McKinney and Kenshimov 2000). We then define a failure year as one in which the ratio of water released to the sea is less than 85 percent of the target flow (a 15 percent risk threshold). Under this scenario, only 44 percent of the 
required flow is released to the sea; in 17 consecutive years in the 30 -year time horizon, flow to the sea is less than 85 percent of the target; and in the most serious case, only 1 percent of the target flow can be accessed. (See Figure 9 for the target flow and computed flow by years.)

Degradation of soil and water quality will probably continue if current irrigation practices are maintained. Soil and water quality in the entire basin will be negatively affected. Modeling results show that the middle stream area will endure the most notable degradation of soil and water quality. Figures 10 and 11 plot the average salt concentration in field drainage and soil salinity in cotton fields under BAS and an alternative scenario (to be described later). From the base year to the last year of the modeling period, the average salt concentration in field drainage will increase from $2.0 \mathrm{~g} / 1$ to $3.5 \mathrm{~g} / 1$, and the average soil salinity in a middle stream area cotton field will increase from 0.7 to $1.3 \mathrm{dS} / \mathrm{m}$ (dS/m stands for deci-Siemens of electrical conductivity per meter of water). A larger increase rate is found in later years of the time horizon for both soil and water salinity.

\subsection{An Alternative Scenario of Infrastructure Improvement and Crop Pattern Change}

An alternative scenario (ALT) to the baseline scenario described above includes investment in infrastructure improvements and crop pattern change. Water conveyance and distribution efficiency improves gradually from $0.50-0.67$ to $0.70-0.75$ in the next 25 years, with larger improvements in downstream areas. Irrigation efficiency gradually improves from 0.55 0.65 to $0.65-0.78$, with larger increases in the middle stream area, where a high risk of waterlogging exists, and a moderate level in the downstream area, leaving substantial amounts of water necessary for salt leaching in the crop fields. The drainage system is significantly better for middle stream and downstream areas, with 52-60 percent of the irrigated area drained in the 
base year and 80 percent of the irrigated area drained by the end of study period. The average annual investment for these improvements is estimated as US\$290 million (Cai, et al. 2001).

The cotton in the region is characterized by high water consumption and high salt tolerance, and planting cotton potentially raises soil salinity in the region. The alternative scenario proposes a dramatic crop pattern change to reduce the currently dominant cotton-forage area (from 60 to 40 percent of the total irrigated area) and to increase irrigated area for wheatmaize (from 10 to 32 percent of the total irrigated area). Moreover, it assumes that the total irrigated area will fall by 10 percent within the study period.

Compared to BAS, ALT performs much better in terms of the sustainability indicators. First, risk indicators for ecological flow release to the Aral Sea improve. ALT achieves 84 percent of the target release, versus 44 percent under BAS. In only two consecutive years is the flow to the sea less than 85 percent of the target, versus 17 years under BAS. And the minimum flow release is 50 percent of the flow target, versus 1 percent under BAS (Figure 9).

Second, as shown in Figures 10 and 11, degradation of water and soil salinity under ALT in future years is not so serious as under BAS, although there is still a slight increase in average salt concentration in field drainage and soil salinity. This implies that additional measures, such as drainage disposal, further reductions in irrigated area, and so on, might be necessary.

Third, ATL results in better economic returns for irrigation than BAS. Figure 12 shows the net irrigation profit under the two scenarios over the time horizon. Under BAS, profits from irrigation decline because of water stress and soil quality (salinity), and year-to-year variations are larger; under ALT, irrigation profits are more stable, and the average in later years is slightly higher than earlier years. Therefore, the modeling results imply that maintaining current irrigation practices (BAS) may hurt the future water use benefit, while the proposed alternative 
scenario will avoid the negative effect on the future and sustain irrigated agriculture without significant damage to the environment.

\subsection{Irrigation versus Hydropower Generation}

The long-term model considers hydropower generation by including net hydropower profit in the total benefit of water uses. Because the magnitude of hydropower profit is far less than the irrigation benefit in the whole river basin, hydropower generation will have lower priority than irrigation in the modeling if no additional policy constraint is included. However, as mentioned before, in the real world, the upstream country Kyrgyzstan-which depends on hydropower for most of its power supply, especially in winter-attempts to hold more of the water that comes in during the growing season in the Toktogul Reservoir for hydropower generation in the winter. In one policy proposal Kyrgyzstan does not hold water in the growing season, and in return the downstream countries help Kyrgyzstan with power generation, for example, by trading coal to Kyrgyzstan at a cheap price. The two scenarios discussed above follow this policy, and both result in much lower hydropower generation than in the current reality, especially in dry years.

Another policy assumes that Kyrgyzstan holds enough water in the Toktogul Reservoir to meet the demand for hydropower generation in winter months as much as possible. To see the trade-off between downstream irrigation and upstream hydropower generation, we model this policy scenario (HYP) by putting a higher priority on hydropower generation than irrigation so that the target of hydropower generation will always be met first if possible. Figure 13 shows the irrigation profit gains and energy loss in nonvegetation months (October-March) of ALT compared to HYP, respectively. Larger gains/losses occur in very dry years $(v d)$ and consecutive dry years $(d)$, while smaller gains/losses occur in very wet $(v w)$ and wet years $(w)$. The largest 
irrigation profit gain is US\$180 million, associated with energy loss of 3,120 million kilowatt hours, which occurs after three consecutive dry years late in the study period. In very wet years, gains/losses are close to zero. In a normal year, gains/losses are affected by the inter-year flow regulation through the storage system in the basin between that year and its previous and following years.

\subsection{Effects of Economic Incentives}

Modeling results show that taxing salt discharges into the river may help solve environmental problems while having only a small effect on irrigation profit. To illustrate the economic incentive of the salt discharge tax, the tax rate was parametrically varied from US\$0 to US\$200 per ton of salt mass in a short-term yearly model. Figure 14 shows irrigation profit and salt discharge versus the salt tax rate. Up to US\$50 per ton, a small increase in the tax rate reduces salt discharges significantly while only slightly reducing irrigation profit.

Another striking result is that investments to improve water distribution systems and irrigation systems could be financed by taxing the increase in profits resulting from the infrastructure improvements. Annualized investment is estimated at US\$299 million. With a tax rate of US\$10 per ton, without considering the transaction cost of implementing the tax system, the tax collected could be as much as US\$251 million, which is 80 percent of the investment.

\section{CONCLUSIONS}

The way to achieve sustainability in irrigation water management is to resolve the conflicts arising from the interactions between water use and the environment, and to balance the benefits between current and future generations. To achieve sustainability, it becomes more urgent than ever before, for decisions at various levels from crop field management, water 
allocation at the basin scale, agricultural policy at the national or regional scale, to follow the newly developed sustainability principles.

The current status of irrigation water management in the Aral Sea region demonstrates the Aral Sea disaster as a prime example for unsustainable irrigation development. Lessons from the Aral Sea problem include the need for an appropriate agricultural development strategy; the need for developing and monitoring an early warning system; and the realization of appropriate actions when creeping processes of change are detected. Sustainable resource use in the region needs to take a long-term approach. Adverse water and soil salinity consequences of irrigation must be fully accounted for, and cumulative changes of water and soil salinity over time must be traced. Tradeoffs between short-term irrigation profits and their associated environmental consequences must be carefully dealt with.

Analytical results show that the current irrigated agriculture cannot be sustained in a sustainable manner since it may put large risk on flow release to the Aral Sea, aggravate the degradation of water and soil salinity, and finally adversely affect crop yield and harvested area. Improvements in the current infrastructure, including water conveyance/distribution efficiency, irrigation efficiency and drainage system, and reducing irrigated cotton area (from $60 \%$ of the total irrigated area in early 1990 to $40 \%$ ) and increasing wheat and maize area (from $10 \%$ of the total irrigated area in early 1990 to $32 \%$ ) are recommended to sustain both agricultural production and the environment in the basin. Annualized investment for the improvements is estimated as US\$299 million.

A penalty tax on salt discharge less than 50 US\$ per ton, as an economic incentive, may help address environmental problems while having only a small effect on irrigation profit. Moreover, investments to improve infrastructure could be financed from taxes on increased 
profits resulting from the infrastructure improvements. However, the taxation and investments will depend on the development of an interstate agreement on basin infrastructure investments, something that the Central Asian republics still need to develop.

\section{REFERENCES}

ASCE (American Society of Civil Engineers) and UN/IHP (United Nations International Hydrologic Program). Committee on Sustainability Criteria, Water Resources Planning, and Management Division. 1998. Sustainability criteria for water resources systems. IV Project M-4.3.

Batchelor, C. 1999. Improving water use efficiency as part of integrated catchment management. Agricultural Water Management 40(2): 249-263.

Cai, X. 1999. Modeling framework for sustainable water resources management. Unpublished Ph.D. dissertation, University of Texas at Austin.

Cai, X., D. C. McKinney, and L. Lasdon. 2001. Solving nonlinear water management models using a combined genetic algorithm and linear programming approach. Advances in Water Resources 24(6): 667-676.

EC (European Commission). 1995. Water resources management \& agricultural production in the central Asian republics, WARMAP Project Report, Vol. 1-6.

FAO (Food and Agriculture Organization of the United Nations). 1996. Food production: The critical role of water. World Food Summit, Rome, Italy.

Glantz, M. H., ed. 1999. Creeping environmental problems and sustainable development in the Aral Sea basin. Cambridge, UK, and New York: Cambridge University Press.

Gleick, P. H. 2000. "The changing water paradigm: a look at twenty-first century water resources development," Water International 25(1): 127-138.

Hutchens, A. O., and P. C. Mann. 1998. Review of water pricing policies, institutions and practices in Central Asia. Technical Report, U.S. Agency for International Development, Environmental Policy and Technology Project, Central Asia Regional EPT Office, Almaty, Kazakstan.

Klotzli, S. 1994. The water and soil crisis in Central Asia-A source for future conflict? ENCOP Occasional Paper No. 11. Center for Security Policy and Conflict Research Zurich/Swiss Peace Foundation, Berne, Zurich.

Loucks, D. P. 2000. Sustainable water resources management. Water International 25(1): 311.

Micklin, P. P. 1993. The shrinking Aral Sea. Geotimes 38(4): 14-18. 
McKinney, D.C. and A.K. Kenshimov (eds.) 2000. Optimization of the Use of Water and Energy Resources in the Syrdarya Basin Under Current Conditions, Technical Report 00-06-W, Environmental Policies and Institutions for Central Asia (EPIC) Program, US Agency for International Development, Almaty, Kazakhstan.

McKinney, D. C., X. Cai, M. W. Rosegrant, C. Ringler, and C. A. Scott. 1999. Modeling water resources management at the basin level: Review and future directions. SWIM Paper No. 6, International Water Management Institute, Colombo, Sri Lanka.

OECD (Organization for Economic Co-operation and Development). The Athens Workshop. 1998. Sustainable management of water in agriculture: Issues and policies.

Postel, S. 1999. Pillar of Sand-Can the irrigation miracle last? New York: W.W. Norton.

Raskin, P., E. Hansen, Z. Zhu, and D. Stavisky. 1992. Simulation of water supply and demand in the Aral Sea Region. Water International 17: 55-67.

Rosegrant, M. W., and C. Ringler. 2000. Impact on food security and rural development of transferring water out of agriculture. Water Policy 1(6): 567-586.

Rosegrant, M.W., C. Ringler, D.C. McKinney, X. Cai, A. Keller, and G. Donoso. 2000. Integrated economic-hydrologic water modeling at the basin scale: the Maipo River basin. Agricultural Economics, Vol.24, No.1, pp.33-46.

Rosegrant, M. W., and R. S. Meinzen-Dick. 1996. Multi-country research program: Water resource allocation: Productivity and environmental impacts (MP-10). Program statement and methodology. Washington, D.C.: International Food Policy Research Institute.

Seckler, D. 1996. The new era of water resources management: From "dry" to "wet" water savings. Research Report, No 1. Colombo, Sri Lanka: International Water Management Institute (IWMI).

UNCED (United Nations Conference on Environment and Development). 1992. Report of the United Nations conference on environment and development, Chap. 5 and 18, Rio de Janeiro.

WCED (World Commission on Environment and Development). 1987. Our common future. ("The Brundtland Report") Oxford University Press.

World Bank. 1992. World development report 1992: Development and the environment. Washington, D.C.

Zolotokrylin, A. N. 1999. Climate flucuations and changes in the Aral Sea Basin within the last 50 years. Chapter 5, in Creeping environmental problems and sustainable development in the Aral Sea basin. Glantz, M. H., eds. Cambridge, UK, and New York: Cambridge University Press. 
Table 1-Runoff and irrigation water withdrawals, selected years, Syr Darya basin (Source: EC 1995)

\begin{tabular}{c|cccc}
\hline & 1961 & 1970 & 1980 & 1990 \\
\hline Annual runoff & 30.0 & 52.1 & 39.8 & 39.3 \\
Irrigation withdrawals & 27.8 & 41.0 & 48.3 & 43.5 \\
Total withdrawals & 30.9 & 47.1 & 56.8 & 53.0 \\
Withdrawal/runoff & $103 \%$ & $90 \%$ & $143 \%$ & $135 \%$ \\
\hline
\end{tabular}

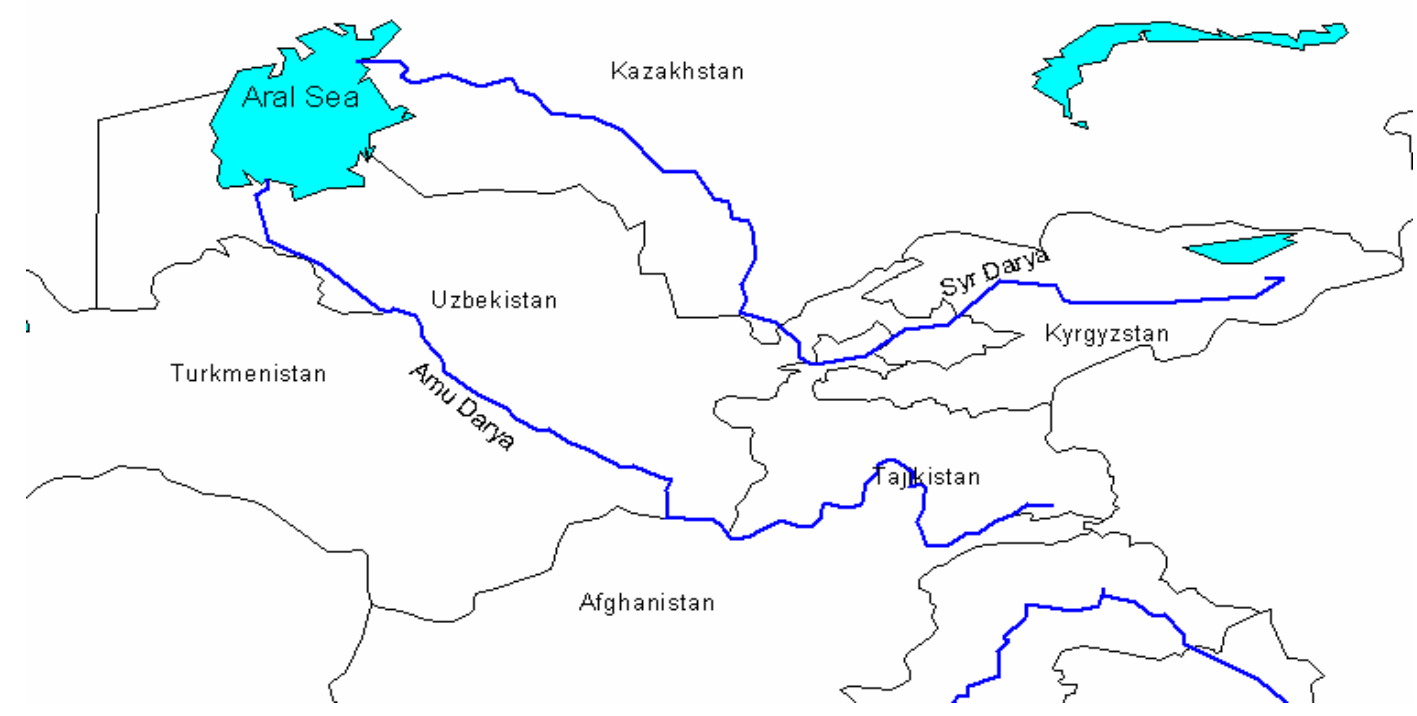

Figure 1-The Aral Sea basin in Central Asia 


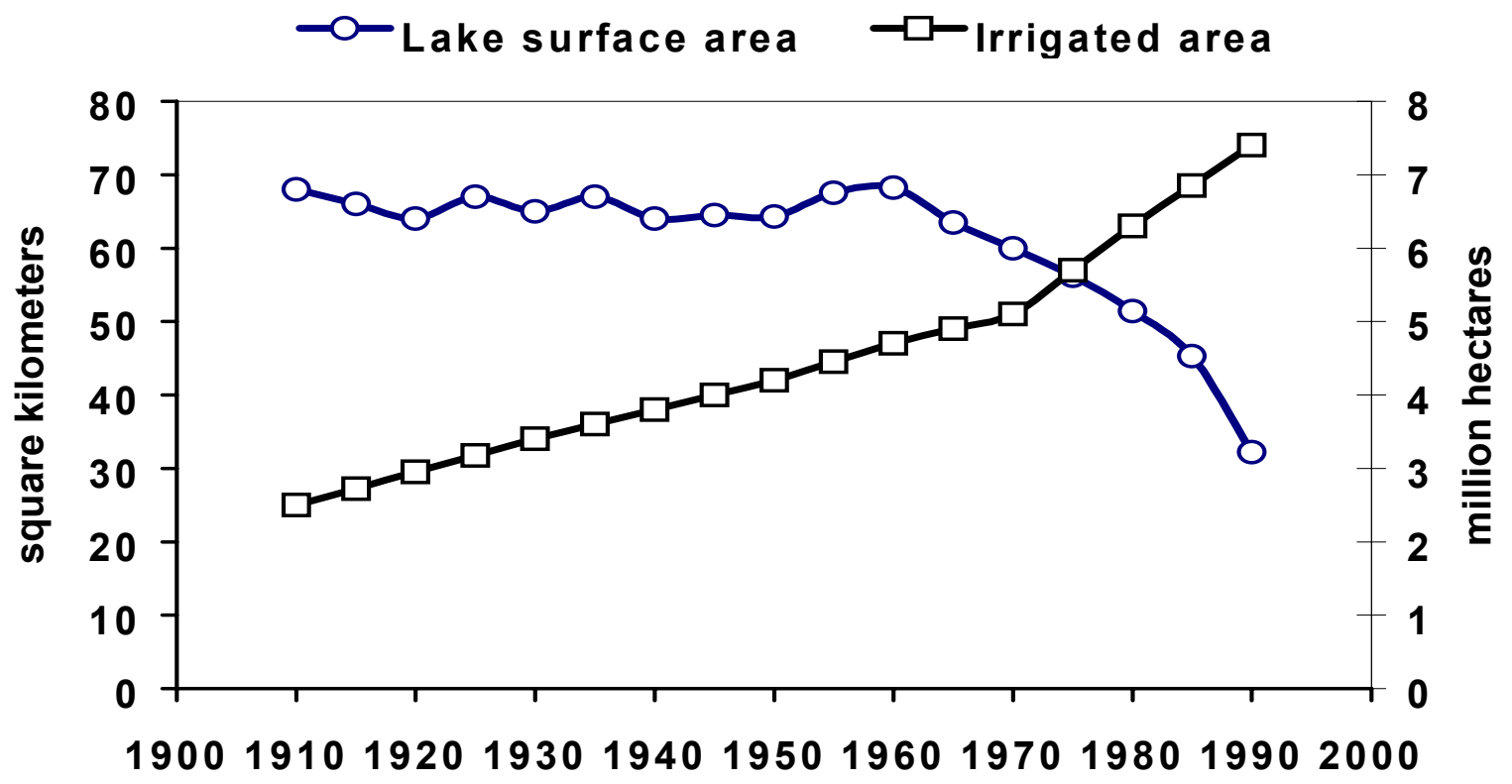

Figure 2-Irrigated area (million hectares) in the Aral Sea basin and surface area (sqare kilometers) of the Aral Sea (Source: Based on Micklin 1993.)

$\sim$ Upstream flow $-\square-$ Downstream flow (to the Aral Sea)

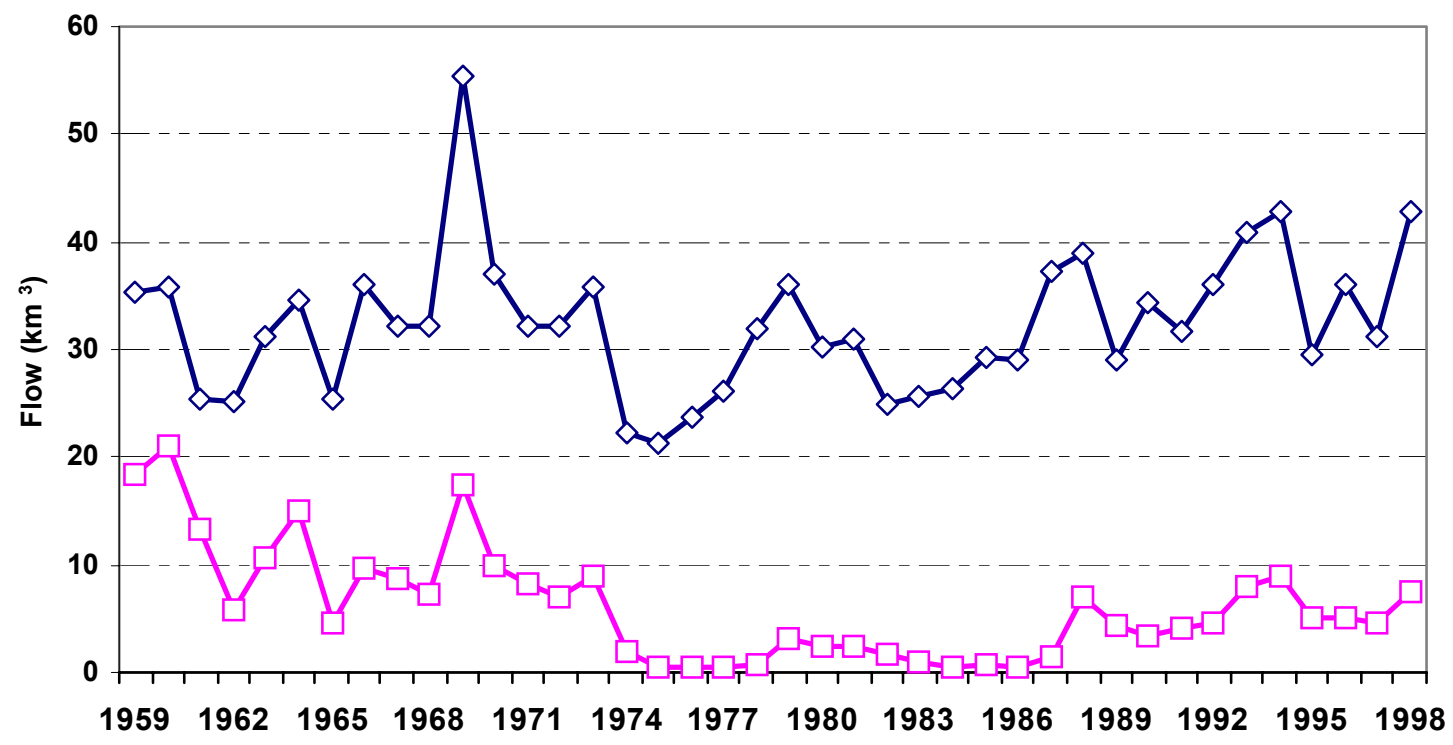

Figure 3-Upstream/downstream runoff of the Syr Darya River (Sources: Glantz (1999) for flows during 1959-88; Personal communication, V. Chub, Uzbekistan Main Hydromet, 2000, for flows during 1989-98.) 


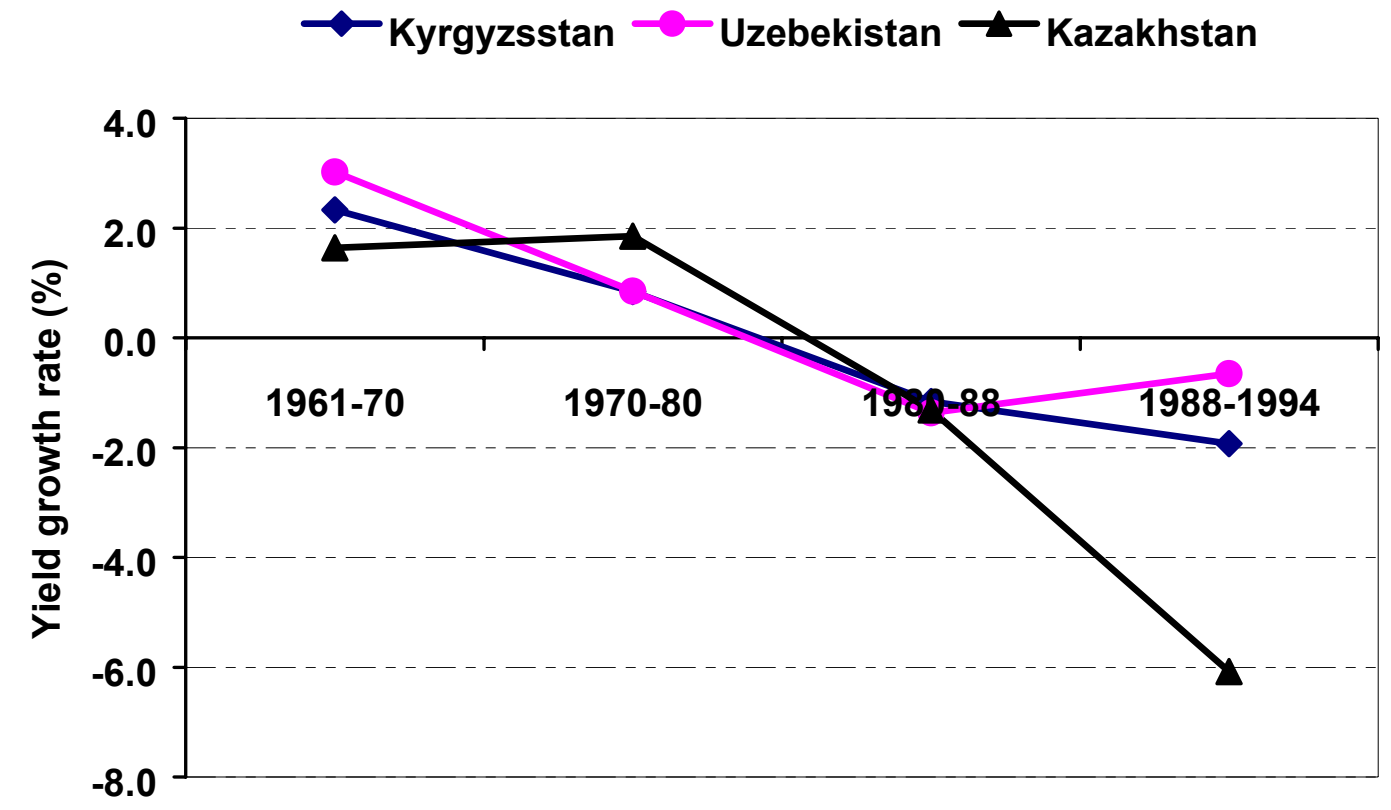

Figure 4-Cotton yield annual growth rate in three Central Asian countries (Source: FAOSTAT, www.fao.org.)

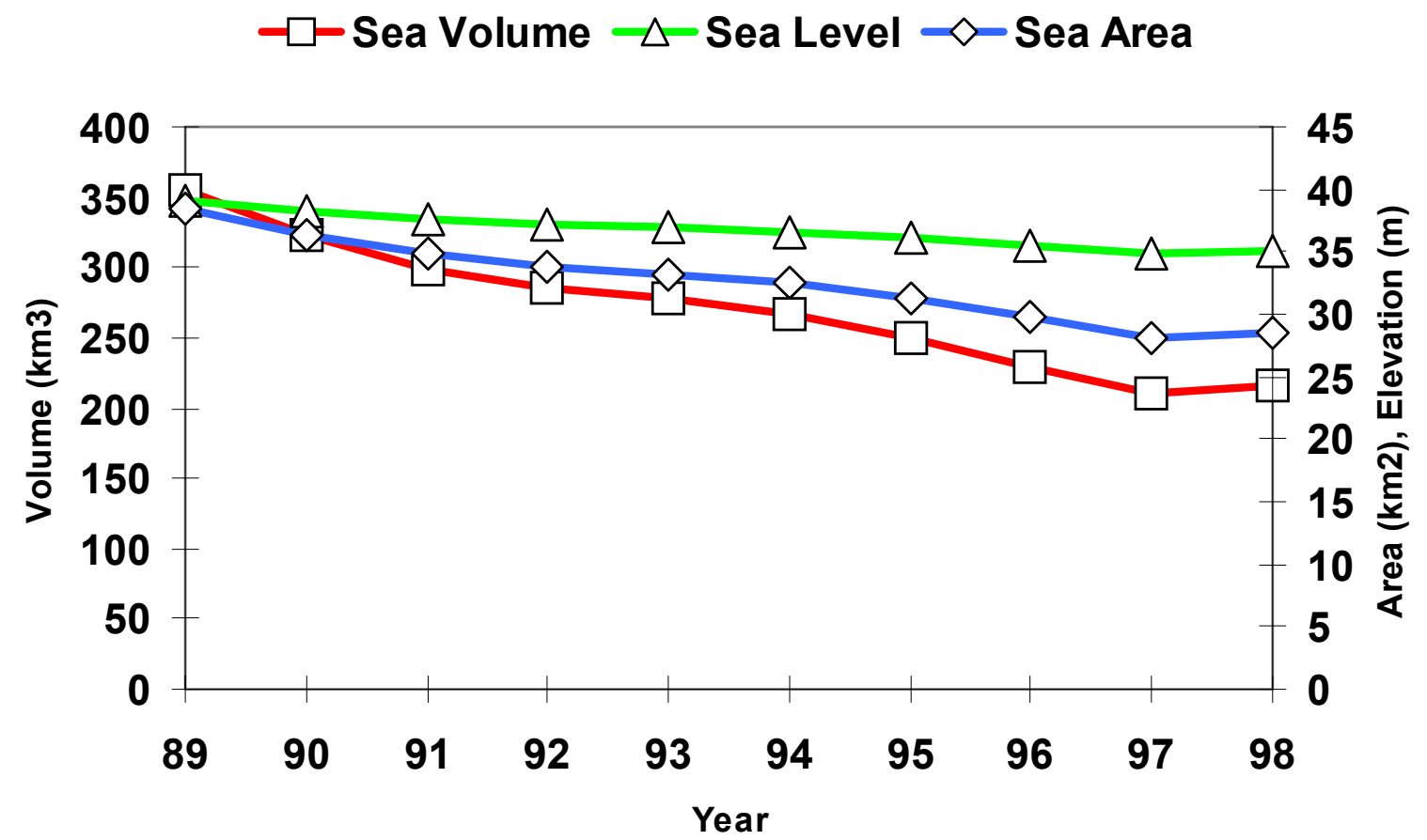

Figure 5-Change of level, area, and volume of the Aral Sea in recent years (Source: Personal communication, V. Chub, Uzbekistan Main Hydromet, 2000.) 


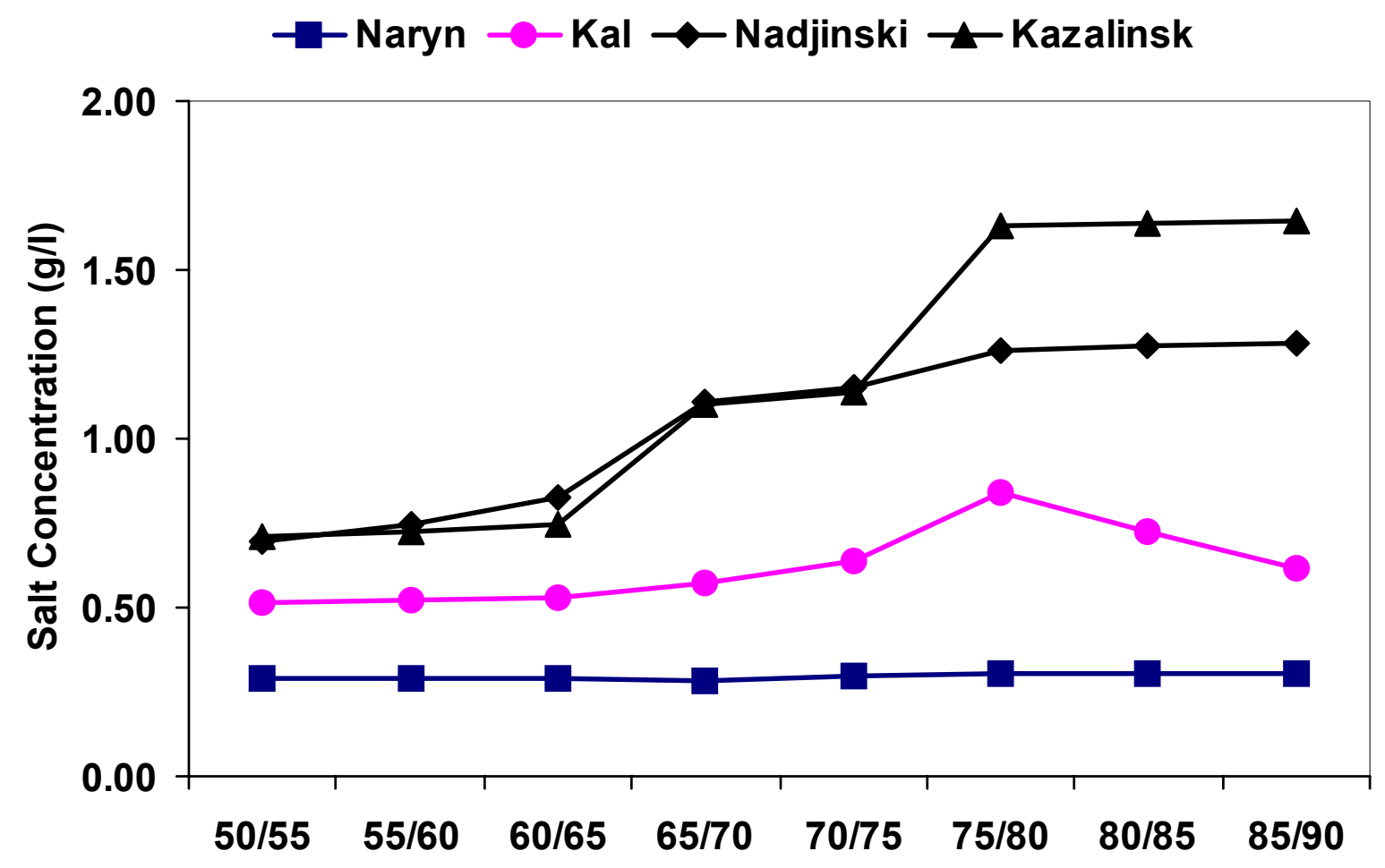

Figure 6-Salinity at selected points in the Syr Darya River from 1950 to 1990 (Source: EC 1995.) 


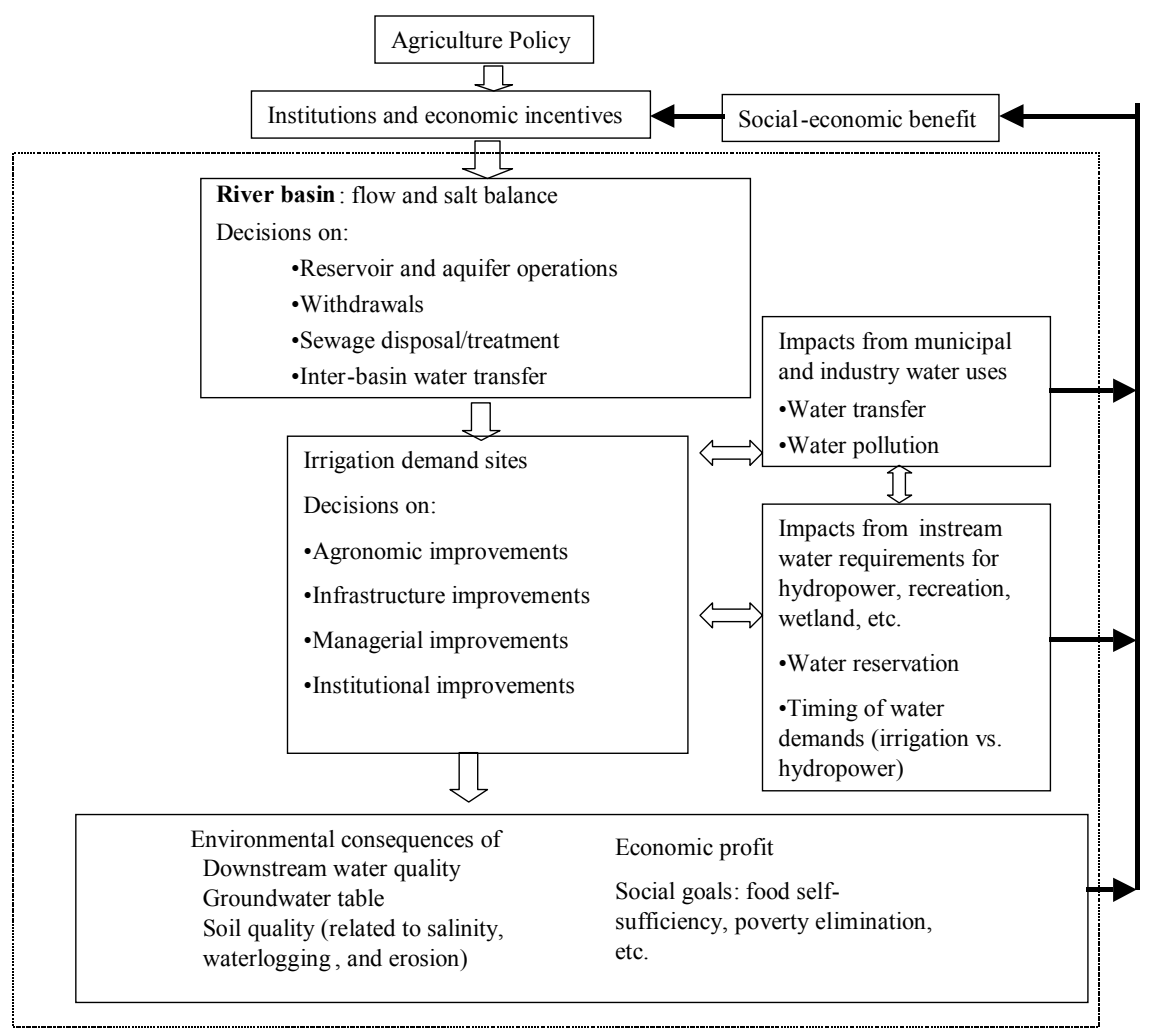

Figure 7-A decision framework for river basin management modeling

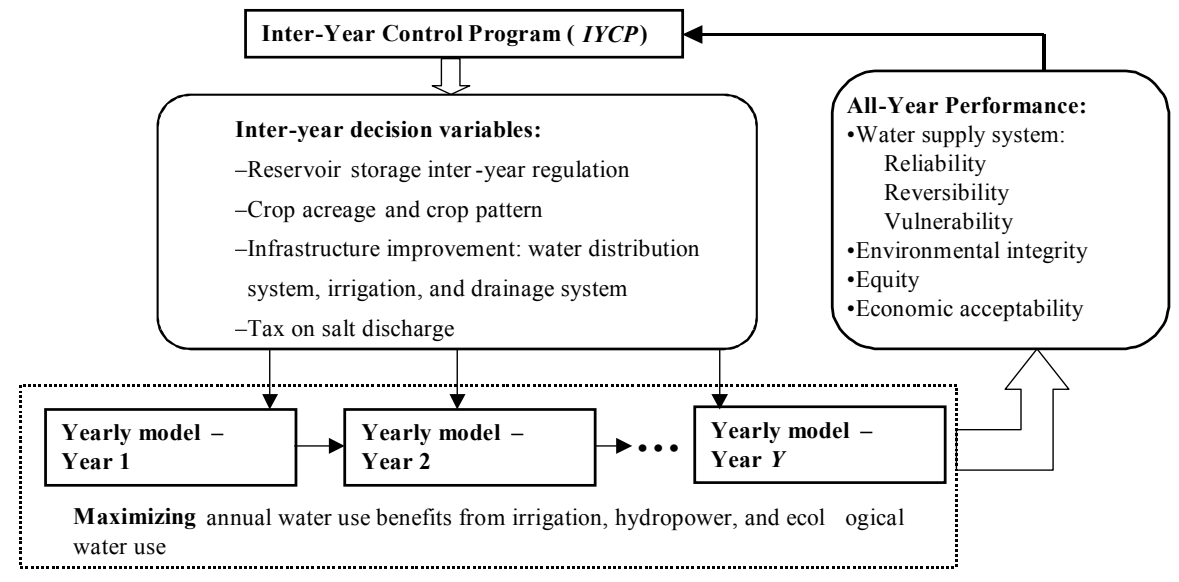

Figure 8-Components and structure of the modeling framework 


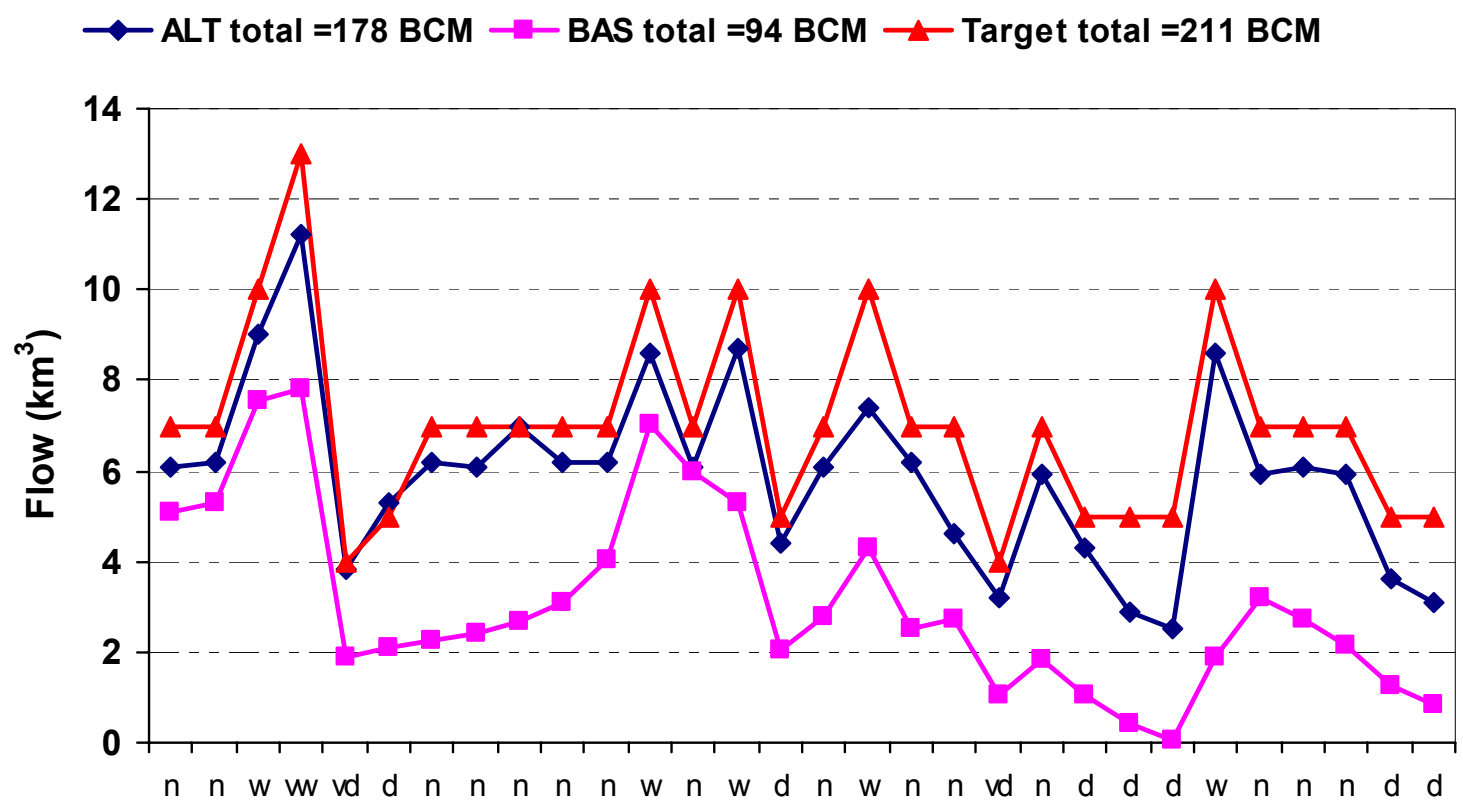

Figure 9-Flow release to the Aral Sea versus hydrologic year series

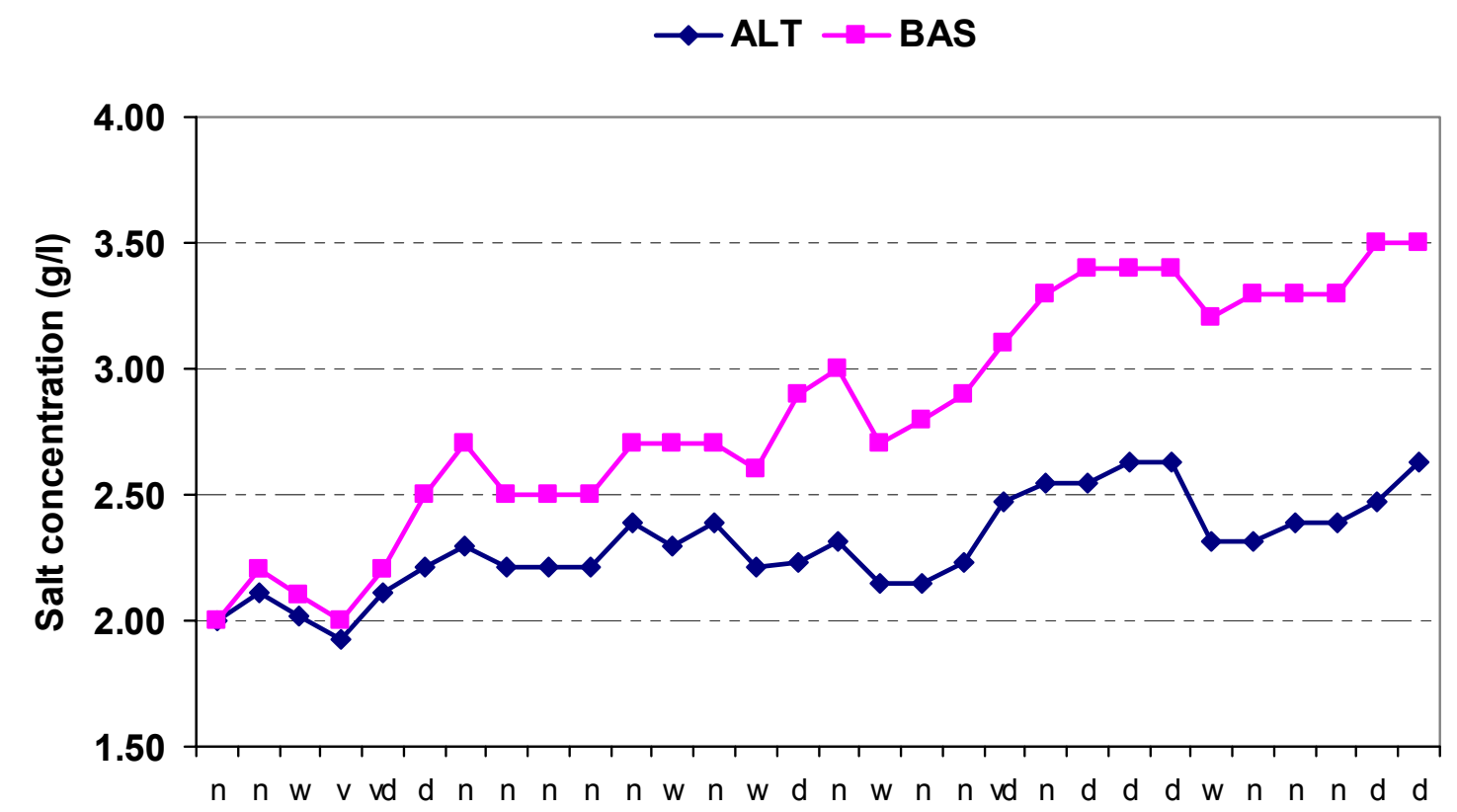

Figure 10-Salt concentration in field drainage (middle stream) versus hydrologic year series 
$\rightarrow$ ALT $\rightarrow$ BAS

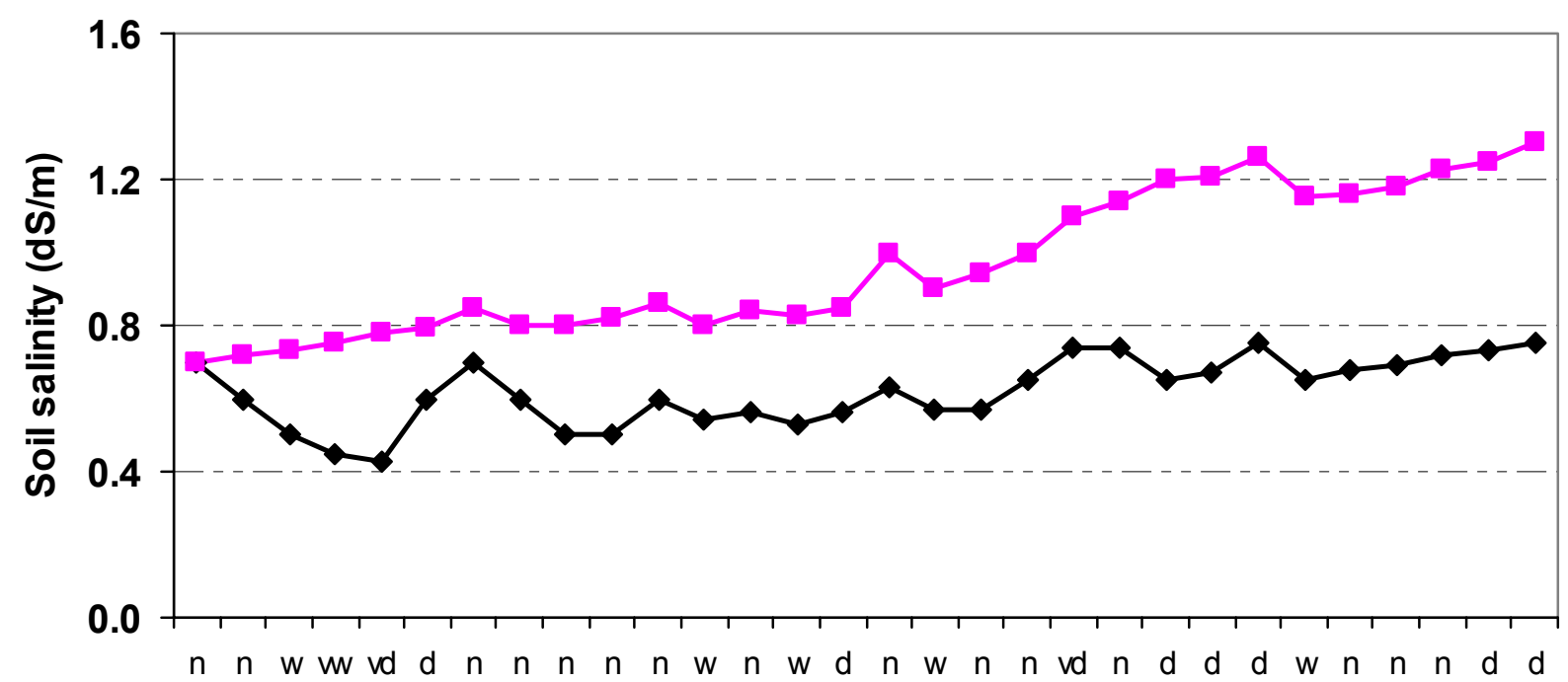

Figure 11-Soil salinity (middle stream, cotton field) versus hydrologic year series

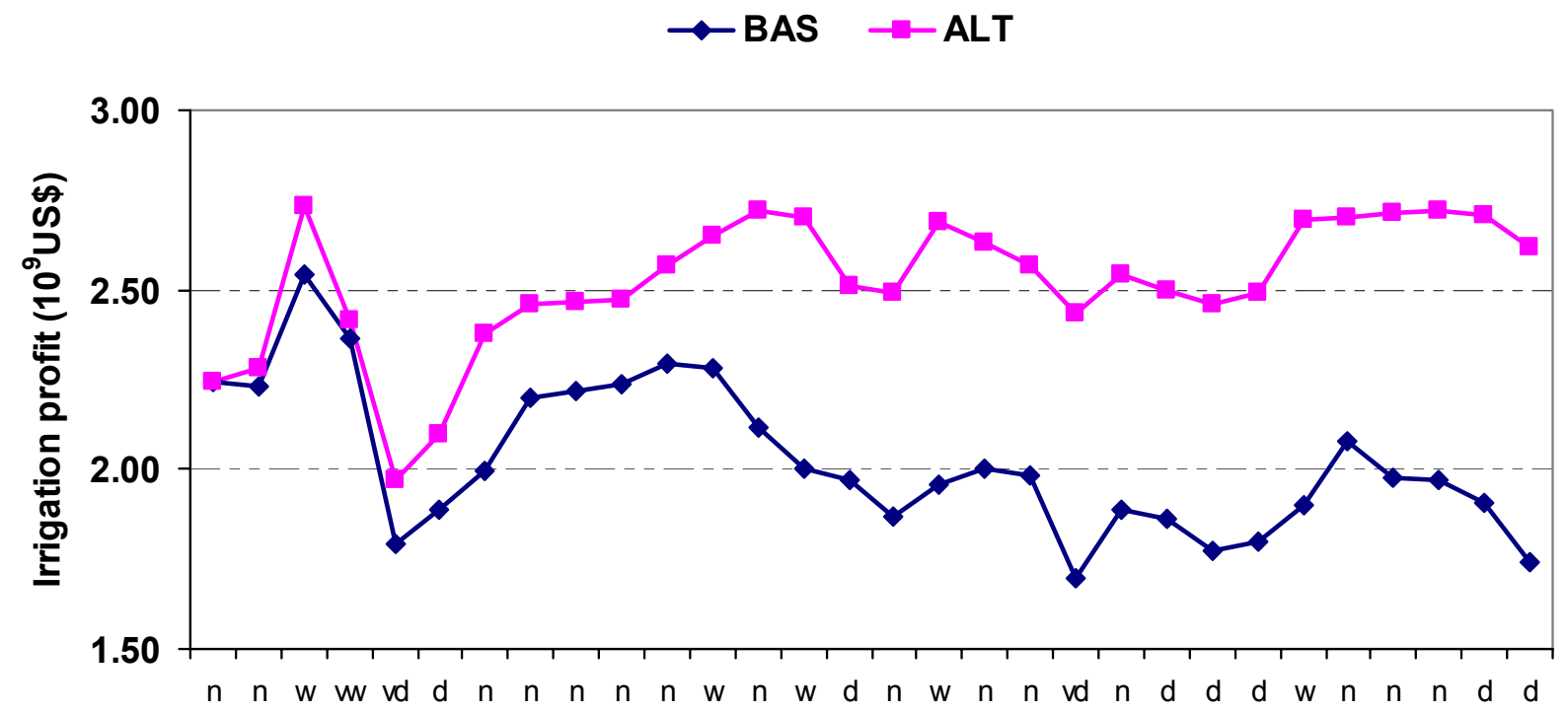

Figure 12-Irrigation profit versus hydrologic year series 
$\rightarrow$ Irrigation profit gain $\rightarrow-$ Hydro energy loss

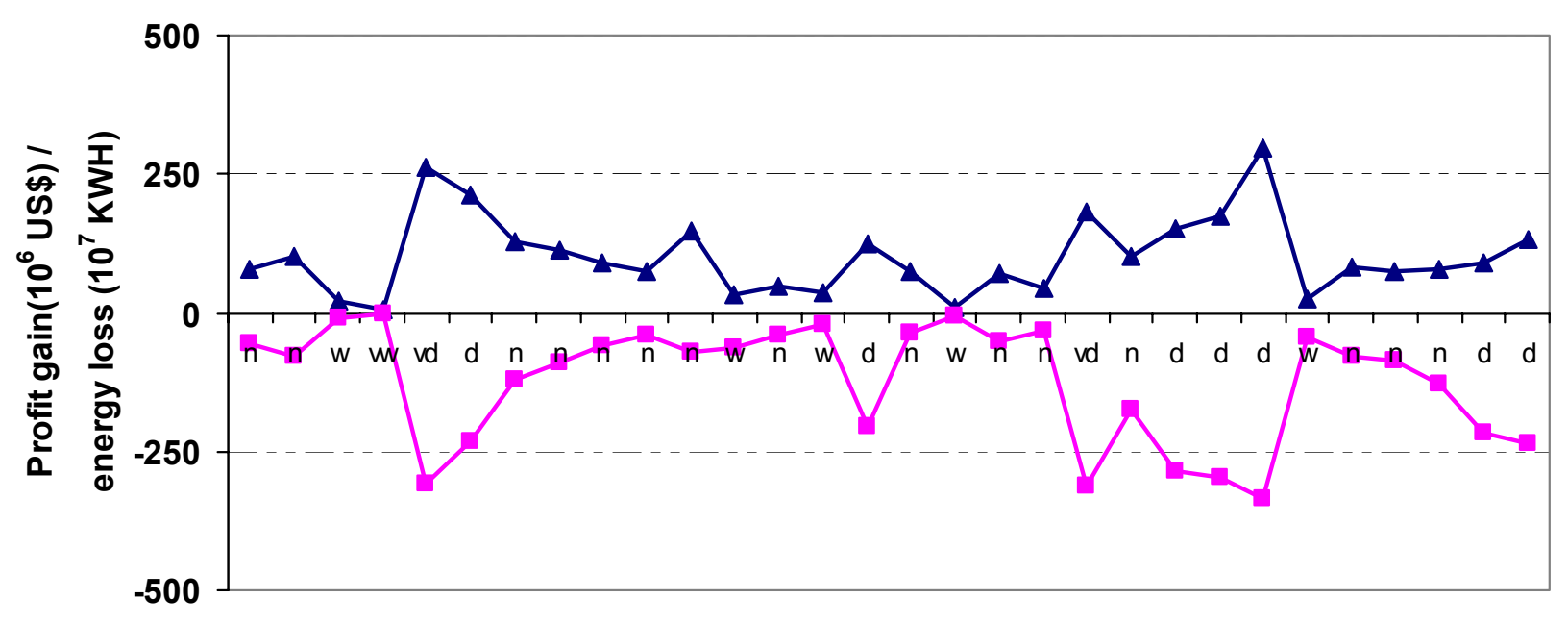

Figure 13-Irrigation profit gains/energy loss under two scenarios

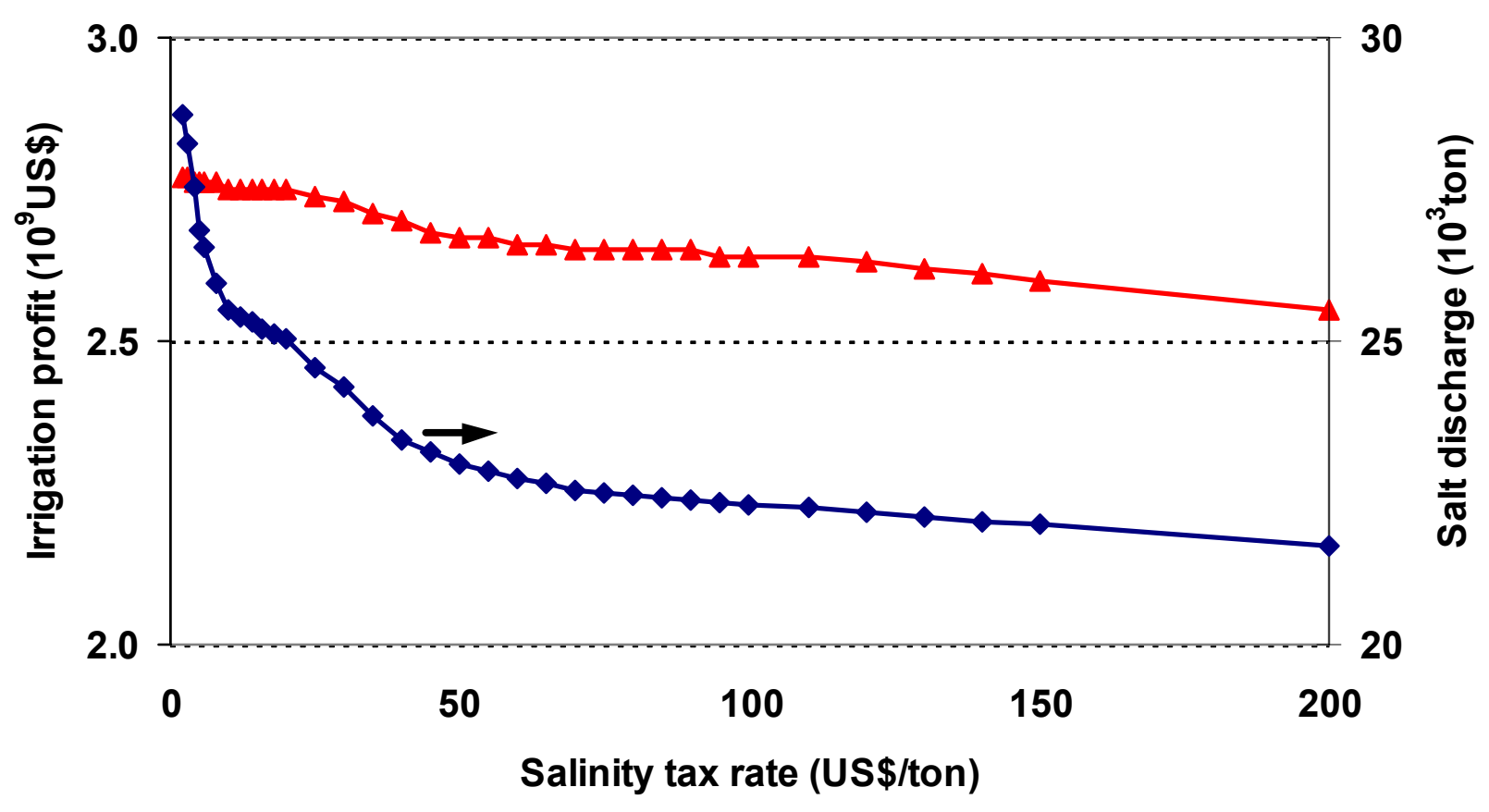

Figure 14-Irrigation profit and salt discharge under various salinity tax rates 